Клюйко Леся

здобувач ступеня $\mathrm{PhD}$ кафедри загальної і соціальної психології та соціології Східноєвропейського національного університету імені Лесі Українки

ORCID iD: 0000-0002-2001-9548

DOI https://doi.org/10.35619/prap_rv.vi13.120

\title{
ПСИХОЛОГІЧНІ ЧИННИКИ ФЕНОМЕНУ СУБ' СКТИВНОГО БЛАГОПОЛУЧЧЯ ТА ЙОГО ВПЛИВУ НА ЗАДОВОЛЕНІСТЬ ЖИТТЯМ ОСОБИСТОСТІ
}

\begin{abstract}
Анотація. В статті проаналізовано феномен суб'єктивного благополуччя та його вплив на задоволеність життям особистості. Проаналізовано, щзо психологічне благополуччя - складний, інтегральний феномен, щзо характеризує позитивне функиіонування особистості та виражається в суб'єктивному відчутті задоволеності життям, реалізації власного потенціалу та залежить від суб’єктивної якості комунікацій особистості з оточуючими. Виявлено, що суб'єктивне благополуччя - складний психологічний феномен, що включає в себе емоційні, когнітивні $і$ конативні компоненти. Розглянуто різні концепції розуміння суб'єктивного благополуччя у науковій літературі. Виділено, що суб'єктивне благополуччя складається із когнітивної оцінки задоволеністю різними сферами власного життя та емоційної оцінки самосприйняття, із задоволеності життям, відсутності негативного афекту та наявності позитивних емочій $і є$ динамічною когнітивно-емоиійною оцінкою людини якості власного життя загалом та окремих його сфер, щуо залежсть, з одного боку, від неї самої та ї̈ особистісних властивостей, з іншого від реалій ї̈ життя. Виявлено, щэо найпопулярнімою $\epsilon$ трикомпонентна модель суб'єктивного благополуччя, в якій виокремлюють когнітивну (очінка власного життя, яка виявляється у задоволеності, уявлення про власне майбутнє), емоційну (позитивні чи негативні емоції, оптимізм, задоволеність сьогоденням і минулим, позитивне ставлення до інших, самоочінка здоров'я, незалежність, аутентичність) та конативну (поведінкову, щьо включає в себе контроль над обставинами та наявність мети власного існування) складові.
\end{abstract}

Ключові слова: особистість, я-концепчія, феномен, благополуччя, суб'єктивне благополуччя, якість життя, задоволеність життям.

Постановка проблеми. В умовах сучасного суспільства задоволеність життям відіграє чи не найвизначнішу роль при формуванні я-концепції людини, зокрема професійної, і об'єднує в собі багато компонентів, серед яких одне із провідних місць займає суб'єктивне благополуччя особистості.

Суб'єктивне благополуччя - це складне соціально-психологічне утворення, що включає в себе емоційні, когнітивні і конативні компоненти та формується у процесі соціально-психологічної діяльності, в системі реальних ставлень особистості до об'єктів навколишньої дійсності та складається на основі соціально-психологічних настанов, цінностей, стратегій поведінки (Курова, 2014). Окрім того, актуальність обраної теми дослідження зумовлена й певними соціальними і економічними змінами в суспільстві, які призводять до суттєвих змін у переживанні людиною власного благополуччя та задоволеності життям загалом.

Аналіз останніх досліджень 3 проблеми. До проблеми суб'єктивного благополуччя зверталися такі вчені як: Аргайл, Ріфф, Дінер, Власова, Горбаль, Гуленко, Гупаловська, Данильченко, Курова, Семків (поняття та структура суб'єктивного благополуччя), Еммонс (вплив життєвих цілей на суб'єктивне благополуччя), Кампбелл, Конверс (якість життя в соціально-психологічному аспекті), Ратманська, Розенбаум, Старченкова, Баранова, Бельскі, Гриценко, Шестопалова (суб'єктивна оцінка якості життя серед різних груп населення), 
Лєбедєва, Константинов, Солдатова (умови та специфіка соціально-психологічної адаптації внутрішньо переміщених осіб та їхнього благополуччя), Хащенко, Журавльов (дослідження критеріїв якості життя та методів його оцінки), Шарапова (вплив економічної кризи на структуру та рівень психологічного благополуччя), Ширяєва (психологічне благополуччя у контексті проблеми екстремальних умов життєдіяльності), Олександров (взаємозв'язок психологічного благополуччя та саморегуляції особистості), Сирцова (взаємозв'язок часової перспективи особистості та психологічного благополуччя). Рат і Хартер виділяють сфери життя як елементи благополуччя, а саме професійне (кар'єра, покликання, професія); фізичне (міцне здоров'я); соціальне (значущість близького оточення і соціальних взаємовідносин); фінансове (фінансова безпека, задоволеність своїм рівнем життя); благополуччя на місці проживання (безпека, власний внесок у розвиток суспільства). Вчені підкреслюють, що успіх повинен бути присутнім у всіх п'яти елементах, оскільки досягнення в одній сфері не може компенсувати невдачу в іншій (Рат, 2010).

Мета статті полягає у теоретичному дослідженні феномену суб'єктивного благополуччя та його впливу на задоволеність життям особистості.

Виклад основного матеріалу дослідження. До проблеми вивчення суб'єктивного благополуччя все частіше звертаються у своїх працях сучасні дослідники, проте якогось одного підходу до розуміння цього феномену не існує. Взагалі, термін «благополуччя особистості» розуміється як багатофакторний конструкт, який являє собою взаємозв'язок фізичних, соціальних, економічних та психологічних факторів (Поліванова \& Гуляєва, 2015).

Поняття «психологічне благополуччя особистості» запропонував Бредбурн, який прирівняв його із суб'єктивним відчуттям щастя і загальною задоволеністю життям та на основі цього створив модель психологічного благополуччя, куди входять: баланс між постійною взаємодією позитивного та негативного афектів і подіями із повсякденного життя. Відповідно до бачення вченого, співвідношення між позитивним і негативним афектами $\epsilon$ показником психологічного благополуччя і в той же час вони відображають задоволеність життям загалом, тобто, якщо рівень позитивного афекту перевищує негативний, то людина відчуває себе щасливою і впевненою, і відповідно, має високий рівень психологічного благополуччя та навпаки, якщо рівень негативних переживань вищий аніж позитивних - то людина відчуває себе нещасною та незадоволеною (Бредбурн, 1969).

Бредбурн (1969) стверджує, що позитивний i негативний аспекти не $\epsilon$ взаємопов'язаними, адже коли ми визначаємо рівень позитивного афекту, то неможливо встановити рівень негативного (він може бути вищими чи нижчим, або ж взагалі рівним позитивному афекту) Ця теорія лягла в основу при розробці концепції суб'єктивного благополуччя.

Взагалі, термін «суб’єктивне благополуччя» ввів у психологічну літературу Дінер (2003)., і воно складається із когнітивної оцінки задоволеністю різними сферами власного життя та емоційної оцінки самосприйняття Сьогодні існує декілька концепції суб'єктивного благополуччя, зокрема, Ріф поділяє їх на гедоністичні і евдемоністичні; Раян і Десі стверджують, що їх теорія самодетермінації поєднує в собі ці два підходи; Кук виділяє чотири підходи i поділяє їх за критерієм загальновживаності - гедоністичний, евдемоністичний, якість життя і оздоровчий; Познякова також виокремлює чотири підходи до розуміння благополуччя (гедоністичний, евдемоністичний, напрям позитивної психології та теорія самодетермінації).

Найвідомішою моделлю суб’єктивного благополуччя є гедоністична трикомпонентна модель Дінера (яка базується на концепції Бредбурна), і складається із задоволеності життям, відсутності негативного афекту та наявності позитивних емоцій.

Дінер розглядав поняття «психологічного благополуччя» та «суб'єктивного благополуччя» не як аналогічні, він писав, що останнє є компонентом першого. Рівень суб'єктивного благополуччя є показником тривожності чи депресивності людини i демонструє рівень відчуття щастя (Дінер, 2003). Дослідник підкреслив, що суб'єктивне благополуччя є відносно стабільною і довгостроковою конструкцією, а стійкі особистісні риси (наприклад, екстраверсія (позитивне сприймання подій), нейротизм (негативне 
сприймання подій)) зумовлюють позитивну чи негативну оцінку життєвих ситуацій (Пахоль, 2017).

Ще однією концепцією дослідження благополуччя особистості є шестифакторна модель Ріфф (1989), до якої входять позитивна оцінка себе і свого минулого, відчуття постійного зростання і розвитку як особистості, наявність цілей і цілеспрямованість, наявність позитивних стосунків 3 оточуючими, володіння комунікативними якостями, почуття самодетермінації. Дослідниця пише, що у той час як традиція суб'єктивного благополуччя формулює благополуччя 3 точки зору загальної задоволеності життям i відчуття щастя (негативний та позитивний афект), традиція психологічного благополуччя людського розвитку і екзистенціональних проблем (евдемонічний підхід) (Кеєс, 2002). Ріфф (1989) вважає, що не все, що відповідає задоволеності життям, сприяє досягненню психологічного благополуччя, адже життєві труднощі, негативний, і навіть травматичний досвід та переживання можуть стати основою для підвищення психологічного благополуччя людини через глибше осмислення життя, усвідомлення власних життєвих цілей, встановлення гармонійних стосунків із іншими людьми, набуття здатності до співпереживання. Отже, відповідно до теорії Ріфф, психологічне благополуччя - складний, інтегральний феномен, що характеризує позитивне функціонування особистості та виражається в суб'єктивному відчутті задоволеності життям, реалізації власного потенціалу та залежить від суб'єктивної якості комунікацій особистості з оточуючими.

Російський дослідник Шаміонов суб’єктивне благополуччя визначає як власне ставлення людини до своєї особистості, життя та процесів, що мають важливе значення для неї з точки зору засвоєння нормативних уявлень щодо зовнішнього й внутрішнього середовища, які характеризуються відчуттям задоволеності (Шаміонов, 2002) і виражає власне ставлення особи до себе, свого життя та процесів, що мають важливе для неї значення 3 точки зору засвоєних нормативних уявлень про «благополучне» зовнішнє та внутрішнє середовище, та яке характеризується переживанням задоволеності (Шаміонов, 2008). Пучкова (2003) виділяє такі ознаки суб'єктивного благополуччя: суб'єктивність (суб'єктивне благополуччя як складова індивідуального досвіду кожного суб'єкта); позитивність виміру (суб'єктивне благополуччя не лише як констатація факту відсутності негативних факторів, необхідність наявності позитивних показників); глобальність виміру (зазвичай для адекватної оцінки суб'єктивного благополуччя особистості слід включити оцінку всіх аспектів життя людини за певний, тривалий період часу). На думку Кулікова (1997) суб'єктивне благополуччя включає в себе особливості ставлення людини до себе i оточуючого світу, а серед основних складових дослідник виділяє когнітивний (ціннісні орієнтації (соціально обумовлена загальна спрямованість, відношення особистості до цілей життєдіяльності, до засобів задоволення цих цілей, тобто до обставин життя, детермінованих соціальними умовами), емоційний та поведінковий компоненти.

Дослідниця Чеботарьова запропонувала типологію суб'єктивного благополуччя, яка оцінює показники задоволеності життям, пристосованості до життя, ціннісні орієнтації, мотивацію, життєстійкість, захисні механізми. Авторка виділяє чотири типи суб'єктивного благополуччя: 1) ворожий тип (невпевнені у своїй здатності досягати цілей, орієнтовані переважно на життєзабезпечення, скаржаться на психосоматичні симптоми і загальний стан здоров'я, рідко використовують захисні механізми); 2) пасивно-агресивний (залежність, пасивність і ворожість у соціальних контактах, досить висока емоційна стійкість, високий рівень креативності, спрямованість на комфорт і насолоду); 3) соціально-активний (оптимізм та інтерес до життя, перевага типово чоловічих видів діяльності, активне використання захисних механізмів, особливо витіснення i заміщення, спрямованість на комфорт $\mathrm{i}$ соціальний статус, близькі стосунки і кохання); 4) комформний (високий рівень прийняття ризику, психічної напруги, низький рівень креативності, використовують раціоналізацію як захисний механізм, емоційно закриті) (Чеботарьова, 2015).

Сучасна українська дослідниця Курова стверджує, що саме суб'єктивне ставлення особистості до життя, його колізій і змін визначає душевне і моральне задоволення власним життям та виділяє такі психологічні ознаки суб'єктивного благополуччя особистості: 

досвіду);

1) суб'єктивність (суб’єктивне благополуччя існує усередині індивідуального

2) позитивність виміру (суб'єктивне благополуччя - не просто відсутність негативних чинників, що характерно для більшості визначень психічного здоров'я; потрібна наявність певних позитивних показників);

3) глобальність виміру (суб’єктивне благополуччя зазвичай включає глобальну оцінку усіх аспектів життя особистості в період від декількох тижнів до десятків років) (Курова, 2015).

Ще одна українська дослідниця Горбаль стверджує, що суб'єктивне благополуччя є динамічною когнітивно-емоційною оцінкою людини якості власного життя загалом та окремих його сфер, що залежить, 3 одного боку, від неї самої та іï особистісних властивостей, 3 іншого - від реалій іiі життя. Авторка підкреслює, що відсутність переживання негативних і наявність позитивних емоцій, уявлення про своє життя, яке відповідає ідеалу існування, формує відкриту, динамічну, однак сталу систему образів себе та свого життя, а психологічне благополуччя характеризується суб'єктивною позицією людини щодо можливості та міри втілення ії потенціалу, тоді як психологічне здоров'я $\epsilon$ реальним, об'єктивним виявом суб'єктивного благополуччя (Горбаль, 2012).

Взагалі, найпопулярнішою є трикомпонентна модель суб'єктивного благополуччя, в якій виокремлюють когнітивну (оцінка власного життя, яка виявляється у задоволеності, уявлення про власне майбутнє), емоційну (позитивні чи негативні емоції, оптимізм, задоволеність сьогоденням і минулим, позитивне ставлення до інших, самооцінка здоров'я, незалежність, аутентичність) та конативну (поведінкову, що включає в себе контроль над обставинами та наявність мети власного існування) складові (Пучкова, 2003).

Висновки і перспективи подальших розвідок. Як ми бачимо із аналізованих наукових праць як зарубіжних, так і вітчизняних вчених, ми можемо говорити про те, що психологічне благополуччя - складний, інтегральний феномен, що характеризує позитивне функціонування особистості та виражається в суб'єктивному відчутті задоволеності життям, реалізації власного потенціалу та залежить від суб'єктивної якості комунікацій особистості 3 оточуючими. Суб'єктивне благополуччя складається із задоволеності життям, відсутності негативного афекту та наявності позитивних емоцій і $є$ динамічною когнітивно-емоційною оцінкою людини якості власного життя загалом та окремих його сфер, що залежить, з одного боку, від неї самої та ії особистісних властивостей, з іншого - від реалій ії життя.

Перспективи подальших розвідок вбачаємо у детальнішому вивчені та аналізі різних компонентів суб'єктивного благополуччя, зокрема при вивченні феномену задоволеності життям та становленні професійної я-концепції особистості.

\section{СПИСОК ПОСИЛАНЬ}

Горбаль, І. С. (2012). Відчуття суб’єктивного благополуччя як передумова та втілення психологічного здоров'я особистості. Науковий вісник Львівського державного університету, 2, 293-303.

Куликов, Л. В. (1997). Субъективное благополучие личности. Ананьевские чтения, 162-164.

Курова, А. В. (2014). Деякі аспекти суб'єктивного благополуччя особистості. Вісник Одеського начіонального університету імені I. І. Мечникова, 1(31), 174-179.

Курова, А. В. (2015). Задоволеність життям та суб'єктивне благополуччя особистості. Вісник Одеського національного університету імені I. I. Мечникова, 2(36), 98-104.

Лукасевич, О. А. (2017). Суб'єктивне благополуччя як психологічний феномен. Проблеми сучасної психології, 12, 110-114.

Пахоль, Б. Є. (2017). Суб'єктивне благополуччя: сучасні і класичні підходи, моделі та чинники. Украӥнський психологічний журнал, 1(3), 80-104.

Поліванова, О. С., Гуляєва, О. В. (2015). До проблеми визначення психологічного змісту поняття "психологічного благополуччя". Вісник Харківського національного університету, 1150, 34-39. 
Пучкова, Г. Л. (2003). Субъективное благополучие как фактор самоактуализации личности. (Автореф. дис. канд. психол. наук). Хабаровск.

Чеботарева, Е. Ю. (2015). Индивидуально-типические характеристики субъективного благополучия. Акмеология образовани, 142-147.

Шамионов, Р. М. (2002). Психология субъективного благополучия: (к разработке интегративной концепции). Мир психологии, 2, 143-148.

Шамионов, Р. М. (2008). Субъективное благополучие личности: психологическая картина и факторы. Саратов: Научная книга.

Bradburn, N. (1969). The Structure of Psychological well-being. Chicago: Aldine Pub. Co.

Diener, E. (2003). Personality, culture, and subjective well-being: Emotional and cognitive evaluations of life. Annual Review of Psychology, 54, 403-425.

Keyes, C. L. M. (2002). Optimizing well-being: The empirical encounter of two traditions. Journal of Personality and Social Psychology, 82, 1007-1022.

Rath, T. (2010). Well-Being: The Five Essential Elements. New York: Gallup press.

Ryff, C. D. (1989). Happiness is everything, or is it? Explorations on the meaning of psychological well-being. Journal of Personality and Social Psychology, 57 (6), 1069-1081.

\section{REFERENCES}

Horbal, I. S. (2012). Vidchuttia subiektyvnoho blahopoluchchia yak peredumova ta vtilennia psykholohichnoho zdorovia osobystosti [Feeling of subjective well-being as a prerequisite and embodiment of a person's psychological health]. Naukovyi visnyk Lvivskoho derzhavnoho universytetu, 2, 293-303. [in Ukrainian].

Kulikov, L. V. (1997). Sub'ektivnoe blagopoluchie lichnosti [Subjective well-being of the individual]. Ananevskie chteniya, 162-164. [in Russian].

Kurova, A. V. (2014). Deiaki aspekty subiektyvnoho blahopoluchchia osobystosti [Some aspects of subjective well-being of the individual]. Visnyk Odes'koho natsional'noho universytetu imeni I. I. Mechnykova, 1(31), 174-179. [in Ukrainian].

Kurova, A. V. (2015). Zadovolenist zhyttiam ta subiektyvne blahopoluchchia osobystosti [Life satisfaction and subjective well-being of the individual]. Visnyk Odes 'koho natsional'noho universytetu imeni I. I. Mechnykova, 2(36), 98-104. [in Ukrainian].

Lukasevych, O. A. (2017). Subiektyvne blahopoluchchia yak psykholohichnyi fenomen [Subjective well-being as a psychological phenomenon]. Problemy suchasnoi psykholohii, 12, 110-114. [in Ukrainian].

Pakhol, B. Ye. (2017). Subiektyvne blahopoluchchia: suchasni i klasychni pidkhody, modeli ta chynnyky [Subjective well-being: modern and classic approaches, models and factors]. Ukrainskyi psykholohichnyi zhurnal, 1(3), 80-104. [in Ukrainian].

Polivanova, O. Ye., \& Huliaieva O. V. (2015). Do problemy vyznachennia psykholohichnoho zmistu poniattia "psykholohichnoho blahopoluchchia" [The problem of determining the psychological content of the concept of "psychological well-being"]. Visnyk Kharkivskoho natsionalnoho universytetu, 1150, 34-39. [in Ukrainian].

Puchkova, G. L. (2003). Sub'ektivnoe blagopoluchie kak faktor samoaktualizatsii lichnosti [Subjective well-being as a factor in the self-actualization of personality]. (Avtoref. dis. kand. psihol. nauk). Habarovsk. [in Russian].

Chebotareva, E. Yu. (2015). Individualno-tipicheskie harakteristiki sub'ektivnogo blagopoluchiya [Individually typical characteristics of subjective well-being]. Akmeologiya obrazovaniya, 142-147. [in Russian].

Shamionov, P. M. (2002). Psihologiya sub'ektivnogo blagopoluchiya: (k razrabotke integrativnoy kontseptsii) [Psychology of subjective well-being: (towards the development of an integrative concept)]. Mir Psihologii, 2, 143-148. [in Russian].

Shamionov, R. M. (2008). Sub'ektivnoe blagopoluchie lichnosti: psihologicheskaya kartina $i$ faktoryi [Subjective well-being of a person: psychological picture and factors]. Saratov: Nauchnaya knyga. [in Russian]. 
Bradburn, N. (1969). The Structure of Psychological well-being. Chicago: Aldine Pub. Co. [in English].

Diener, E. (2003). Personality, culture, and subjective well-being: Emotional and cognitive evaluations of life. Annual Review of Psychology, 54, 403-425. [in English].

Keyes, C. L. M. (2002). Optimizing well-being: The empirical encounter of two traditions. Journal of Personality and Social Psychology, 82, 1007-1022. [in English].

Rath, T. (2010). Well-Being: The Five Essential Elements. New York: Gallup press. [in English].

Ryff, C. D. (1989). Happiness is everything, or is it? Explorations on the meaning of psychological well-being. Journal of Personality and Social Psychology, 57 (6), 1069-1081. [in English].

\title{
PSYCHOLOGICAL FACTORS OF THE PHENOMENON OF SUBJECTIVE WELL- BEING AND ITS EFFECT ON PERSONALITY LIFE SATISFACTION
}

\author{
Lesia Kliuiko \\ PhD student of the Department of General, \\ Social Psychology and Sociology \\ Lesya Ukrainka Eastern European National University \\ ORCID iD: 0000-0002-2001-9548 \\ DOI https://doi.org/10.35619/prap_rv.vi13.120
}

\begin{abstract}
Annotation. The article analyzes the phenomenon of subjective well-being and its effect on personality life satisfaction. It has been revealed that contemporary researchers more often refer to the problem of studying the subjective well-being in their works; however there is no single approach to the understanding of this phenomenon. Generally the term "personality well-being" is understood as multifactorial construct, which is considered as interrelation of physical, social, economic and psychological factors. It is emphasized that psychological well-being is a complex, integral phenomenon, which characterizes positive personality functioning and which is expressed in subjective sense of life satisfaction, realization of own potential and depends on subjective quality of personality communication with surrounding people. It has been determined that subjective well-being is complex psychological phenomenon that includes emotional, cognitive and connative components. Different concepts of understanding of subjective well-being in scientific literature have been reviewed. It is highlighted that subjective well-being consists of cognitive assessment of satisfaction with different spheres of own life and emotional assessment of selfperception, life satisfaction, absence of negative affect and presence of positive emotions; and represents personality dynamic cognitive and emotional assessment of own life quality generally and its individual spheres, on the one hand depending on oneself and own personality properties, on the other hand - on own life realities. It is analyzed that the basis of subjective well-being concept became the theory of N.M. Bradburn, who compared psychological well-being with subjective sense of happiness and general satisfaction with life, and created the model of psychological well-being on this basis, which includes: balance between constant interaction of positive and negative affects and daily life events. It is determined that three-component model of subjective well-being is the most popular, where distinguish the cognitive constituent (assessment of one's own life, which is expressed in satisfaction, ideas about one's future), the emotional constituent (positive or negative emotions, optimism, satisfaction with present and past, positive attitude towards others, health self-esteem, independence, authenticity) and the conative constituent (behavioral, which includes control over circumstances and presence of one's own goals of existence).
\end{abstract}

Keywords: personality, Self-concept, phenomenon, well-being, subjective well-being, life quality, life satisfaction. 